\title{
KOMENTAR KASAR NETIZEN UNTUK VIDEO DEBAT FINAL PILKADA DKI 2017 DI CHANNEL YOUTUBE \\ (Studi Etnografi Virtual tentang Komentar Kasar Netizen untuk Video Debat Final Pilkada DKI 2017 di Channel YouTube CNN Indonesia)
}

\author{
Rachmaniar, Renata Anisa \\ Fakultas Ilmu Komunikasi Universitas Padjadjaran \\ Email: rachmaniar01@gmail.com
}

\begin{abstract}
The purpose of this research is to know the rough netizen comments related video Debat Final Pilkada DKI 2017 on the YouTube channel CNN Indonesia. The method used in this study is a qualitative method with a virtual ethnography approach to analyze rough comments netizen related video Debat Final Pilkada DKI 2017 on the YouTube channel CNN Indonesia. The main object of this research is video Debat Final Pilkada DKI 2017 on the YouTube channel of CNN Indonesia. Data collection techniques are conducted through participatory observation and literature studies. The results of this study indicate that rough netizen comments related video Debat Final Pilkada DKI 2017 on the YouTube channel of CNN Indonesia are: 1) netizens often insulting candidate pairs that are not his choice; 2) netizens mutually insulting other netizens supporting one candidate pair; and 3) netizens argue with other netizens related to their candidate pairs.
\end{abstract}

Keywords: video, pilkada DKI, YouTube, virtual ethnography

\section{PENDAHULUAN}

Lembaga riset pasar e-Marketer mengungkap bahwa populasi netter Tanah Air mencapai 83,7 juta orang pada 2014. Angka tersebut memiliki arti setidaknya setiap sebulan sekali setiap orang Indonesia mengakses internet. eMarketer memperkirakan bahwa netter Indonesia bakal mencapai 112 juta orang pada $2017 .^{1}$

\begin{tabular}{|c|c|c|c|c|c|c|}
\hline & 2013 & 2014 & 2015 & 2016 & 2017 & 2018 \\
\hline 1. China* & 620.7 & 643.6 & 669.8 & 700.1 & 738.2 & 77.0 \\
\hline 2. US"* & 245.0 & 252.9 & 259.3 & 264.9 & 269.7 & 274.1 \\
\hline 3 inds & 167.2 & 2156 & 2523 & 283.8 & 313.8 & 346.3 \\
\hline 4. Brazl & 99.2 & 107.7 & 1137 & 119.8 & 123.3 & 125.9 \\
\hline 5. Japan & 100.0 & 102.1 & 103.6 & 104.5 & 105.0 & 105.4 \\
\hline 6. Indonesia & 72.8 & 83.7 & 93.4 & 102.8 & 112.6 & 123.0 \\
\hline 7. Russia & 77.5 & 82.9 & 873 & 91.4 & 94.3 & 96.6 \\
\hline 8. Germany & 59.5 & 61.6 & 622 & 62.5 & 62.7 & 62.7 \\
\hline 9. Mexico & $\$ 3.1$ & 594 & 65.1 & 70.7 & 75.7 & 80.4 \\
\hline 10. Nigeria & 51.8 & 57.7 & 632 & 69.1 & 76.2 & 84.3 \\
\hline 11. UK * & 48.8 & 50.1 & 51.3 & 52.4 & 53.4 & 54.3 \\
\hline 12. France & 48.8 & 49.7 & 50.5 & 51.2 & 51.9 & 52.5 \\
\hline 13. Philippines & 42.3 & 48.0 & 537 & 59.1 & 64.5 & 69.3 \\
\hline
\end{tabular}

\begin{tabular}{|c|c|c|c|c|c|c|}
\hline 14. Turkey & 36.6 & 41.0 & 447 & 47.7 & 50.7 & 53.5 \\
\hline 15. Vietnam & 36.6 & 40.5 & 444 & 48.2 & 52.1 & 55.8 \\
\hline 16. South Kores & 40.1 & 40.4 & 40.6 & 40.7 & 40.9 & 41,0 \\
\hline 17. Esypt & 34.1 & 360 & 38.3 & 40.9 & 43.9 & 47.4 \\
\hline 18. Italy & 34.5 & 35.8 & 36.2 & 37.2 & 37.5 & 37.7 \\
\hline 19. Spain & 30.5 & 31.6 & 323 & 33.0 & 33.5 & 33.9 \\
\hline 20. Canada & 27.7 & 28.3 & 28.8 & 29.4 & 29.9 & 30.4 \\
\hline 21. Argentina & 25.0 & 27.1 & 290 & 29.8 & 30.5 & 31.1 \\
\hline 22. Colombia & 24.2 & 26.5 & 28.6 & 29.4 & 30.5 & 31.3 \\
\hline 23. Thailand & 22.7 & 24.3 & 260 & 27.6 & 29.1 & 30.6 \\
\hline 24. Poland & 226 & 229 & 233 & 23.7 & 240 & 24.3 \\
\hline 25. South Africa & 20.1 & 227 & 250 & 27.2 & 29.2 & 30.9 \\
\hline Worldwide*t. & 2.692 .9 & 2.892 .7 & $3,072.6$ & 3.246 .3 & 3.419 .9 & $3,600.2$ \\
\hline \multicolumn{7}{|c|}{$\begin{array}{l}\text { Note: individuals of any ase who use the internet from any location via ary } \\
\text { device at least once per month, cexcludes Hong Kong. "forecast from Aug } \\
2014 ; . \cdots \text { includes countries not listed } \\
\text { Source: eMarketer, Nov 20i4 }\end{array}$} \\
\hline
\end{tabular}

\footnotetext{
${ }^{1}$ Kementerian Komunikasi dan Informatika Republik Indonesia. (2014). Pengguna Internet Indonesia Nomor Enam Dunia. Diakses pada 23 Agustus 2016, dari https://kominfo.go.id/content/detail/4286/penggunainternet-indonesia-nomor-enam-dunia/0/sorotan_media
} 
Fakta tersebut salah satunya dapat terlihat dari meningkatnya jumlah penonton YouTube dan berkurangnya jumlah penonton televise.

Berdasar hasil penelitian firma Mildward Brown diketahui bahwa 30 persen populasi di Indonesia, 52 persen di antaranya menonton video di internet - perilaku pemilik smartphone di Indonesia lebih banyak nonton video di internet ketimbang nonton tayangan di televisi

Orang Indonesia kini lebih banyak nonton video di internet ketimbang nonton tayangan di televisi. Hal tersebut terungkap dari hasil penelitian firma Millward Brown tentang perilaku pemilik smartphone di Indonesia. Lebih spesifiknya, dari 30 persen populasi di Indonesia, 52 persen di antaranya menonton video di internet, salah satunya YouTube, melalui smartphone, tablet, atau laptop. $^{2}$

Pihak YouTube sendiri menyatakan bahwa jumlah penonton mereka saat ini lebih banyak dari penonton TV.

Pihak YouTube menyatakan bahwa Interpublic Group, salah satu perusahaan pengiklan terbesar di dunia, berencana untuk memindahkan dana sebesar USD250 juta dari iklan untuk televisi menjadi iklan untuk YouTube. $^{3}$

Fakta-fakta tersebut menyuratkan bahwa keberadaan YouTube menjadi media

${ }^{2}$ Bohang, Fatimah Kartini. (2015). TV

Ditinggalkan, Ini Tontonan Favorit Baru

Orang Indonesia. Diakses pada 23 Agustus

2016, dari

http://tekno.kompas.com/read/2015/11/25/123 10007/TV.Ditinggalkan.Ini.Tontonan.Favorit. Baru.Orang.Indonesia

${ }^{3}$ Amalia, Ellavie Ichlasa. (2016). Bos YouTube: Penonton TV Berkurang, Penonton Kami Bertambah. Diakses pada 23 Agustus 2016, dari http://teknologi.metrotvnews.com/newsteknologi/Obz9BJeN-bos-YouTube-penonton-tvberkurang-penonton-kami-bertambah yang dipilih oleh khalayak. Tidak mengherankan jika akhirnya ada beberapa stasiun televisi yang mengupload tayangan tertentu ke dalam sebuah channel YouTube. Salah satu tayangan yang diupload oleh beberapa stasiun televise adalah Debat Final Pilkada DKI 2017. Video tersebut mendapat perhatian netizen, dan mengundang komentar yang cukup kasar.

Atas hal tersebut, penulis menjadi tertarik untuk mengetahui komentar kasar netizen terkait isi video tersebut.

Untuk menjawab pertanyaan tersebut, penulis menggunakan penelitian kualitatif dengan tradisi penelitian etnografi virtual.

Penelitian kualitatif adalah penelitian yang bersifat empiris (dapat diamati dengan pancaindera sesuai dengan kenyataan), dengan pengamatan atas data tidak didasarkan pada ukuran-ukuran matematis yang terlebih dulu ditetapkan peneliti dan harus disepakati (direplikasi) oleh pengamatan lain, tetapi berdasarkan ungkapan subjek penelitian, sebagaimana yang dikehendaki dan dimaknai oleh subjek penelitian. Pendekatan kualitatif menggunakan konsep kealamiahan (kecermatan, kelengkapan, atau orisinalitas) data dan apa yang sebenarnya terjadi di lapangan.

Pendekatan kualitatif terutama layak untuk menelaah sikap atau perilaku dalam lingkungan yang agak artifisial, seperti dalam survei atau eksperimen. Peneliti kualitatif lebih menekankan proses dan makna ketimbang kuantitas, frekuensi atau intensitas (yang secara matematis dapat diukur), meskipun peneliti tidak mengharamkan statistik deskriptif dalam bentuk distribusi frekuensi atau presentase untuk melengkapi analisis datanya (Mulyana, 2007:11).

Sementara tradisi penelitian etnografi virtual adalah metode etnografi yang dilakukan untuk melihat fenomena sosial dan kultur pengguna di ruang siber (Nasrullah, 2014: 171). Etnografi virtual mempertanyakan asumsi yang sudah berlaku secara umum tentang internet, menginterpretasikan sekaligus reinterpretasi 
internet sebagai sebuah cara sekaligus medium yang digunakan untuk berkomunikasi, merupakan "ethnography in, of and trough the virtual" - interaksi tatap muka atau face to face tidak diperlukan (Hine, 2001).

\section{TINJAUAN PUSTAKA KOMUNIKASI}

Kata atau istilah "komunikasi" (Bahasa Inggris "communication") berasal dari bahasa Latin "communicates" atau "communication" atau "cummunicare" yang berarti "berbagi" atau "menjadi milik bersama", dengan definisi kontemporer menyatakan bahwa komunikasi berarti "mengirim pesan" - proses penyampaian pesan oleh komunikator kepada komunikan melalui media yang menimbulkan efek tertentu (Lasswell, 1972).

Komunikasi menurut Trenholm dan Jensen adalah suatu proses dimana sumber mentransmisikan pesan kepada penerima melalui beragam saluran (Fajar, 2009:31), dimana ditinjau dari jumlah komunikan, komunikasi diklasifikasikan menjadi tiga bagian:

a. Komunikasi pribadi (personal communication)

- Komunikasi intrapribadi

- Komunikasi antarpribadi

b. Komunikasi kelompok (group communication)

- Komunikasi kelompok kecil, seperti : ceramah, forum, simposium, diskusi, seminar, dan lain-lain

- Komunikasi kelompok besar

c. Komunikasi Massa (mass communication)

- Komunikasi media massa cetak/pers, seperti surat kabar dan majalah,

- Komunikasi media massa elektronik, seperti : radio, televisi, dan film

(Effendy, 1993:53-54)

\section{Komunikasi Massa}

Komunikasi massa menurut Bittner adalah pesan yang dikomunikasikan melalui media massa pada sejumlah orang besar". Sedangkan komunikasi massa menurut Gerbner adalah produksi dan distribusi yang berlandaskan teknologi dan lembaga dari arus pesan yang kontiniu serta paling luas dimiliki orang dalam masyarakat industri (Ardianto, 2004:4), dengan efek:

a. kognitif, dimana pesan komunikasi massa mengakibatkan khalayak berubah dalam hal pengetahuan, pandangan, dan pendapat terhadap sesuatu yang diperolehnya - berkaitan dengan transmisi pengetahuan, keterampilan, kepercayaan, atau informasi

b. afektif, dimana pesan komunikasi massa mengakibatkan berubahnya perasaan tertentu dari khalayak berkaitan dengan emosi, sikap, atau nilai

c. konatif, dimana pesan komunikasi massa mengakibatkan orang mengambil keputusan untuk melakukan atau tidak melakukan sesuatu - berkaitan dengan prilaku nyata yang dapat diamati (pola-pola tindakan, kegiatan, atau kebiasaan berprilaku) (Ardianto, 2004:39).

Adapun media komunikasi yang termasuk dalam media massa adalah surat kabar dan majalah, disebut sebagai media cetak; media film; radio siaran, dan televisi, disebut sebagai media elektronik (Ardianto, 2004:3).

\section{Televisi}

Televisi berasal dari kata tele - jauh dan visi berarti penglihatan. Televise berarti melihat lebih jauh (Setyabudi, 1998:2). Hal ini meliputi:

a. Pemancar yang berfungsi mengubah dan memancarkan sinyal-sinyal gambar bersama suara, sehingga dapat 
diterima oleh pesawat televisi penerima pada jarak yang cukup jauh

b. Televisi penerima yang berfungsi untuk menangkap sinyal-sinyal gambar dan suara kemudian mengubahnya kembali, sehingga apa yang dipancarkan oleh transmisi televisi tadi dapat dilihat dan didengar seperti keadaan aslinya. Selanjutnya televisi dikatakan sebagai alat untuk melihat dan mendengar dari tempat jauh - media audio visual, media pandang dengar.

\section{Video}

Menurut Kamus Besar Bahasa Indonesia, video berarti:

a. bagian yang memancarkan gambar pada pesawat televisi;

b. rekaman gambar hidup atau program televisi untuk ditayangkan lewat pesawat televisi

Sementara dalam Wikipedia disebutkan bahwa video adalah teknologi pengiriman sinyal elektronik dari suatu gambar bergerak. Aplikasi umum dari sinyal video adalah televisi, tetapi dia dapat juga digunakan dalam aplikasi lain di dalam bidang teknik, saintifik, produksi dan keamanan. Kata video berasal dari kata Latin, "Saya lihat".

\section{YouTube}

Dalam Wikipedia disebutkan bahwa YouTube adalah sebuah situs web berbagi video yang dibuat oleh tiga mantan karyawan PayPal pada Februari 2005. Situs ini memungkinkan pengguna mengunggah, menonton, dan berbagi video. Perusahaan ini berkantor pusat di San Bruno, California, dan memakai teknologi Adobe Flash Video dan HTML5 untuk menampilkan berbagai macam konten video buatan pengguna, termasuk klip film, klip TV, dan video musik. Selain itu ada pula konten amatir seperti blog video, video orisinal pendek, dan video pendidikan.

$\begin{array}{cll}\text { Kebanyakan } & \text { konten di } & \text { YouTube } \\ \text { diunggah oleh individu, } & \text { meskipun }\end{array}$

perusahaan-perusahaan media seperti CBS, BBC, Vevo, Hulu, dan organisasi lain sudah mengunggah material mereka ke situs ini sebagai bagian dari program kemitraan YouTube. Pengguna tak terdaftar dapat menonton video, sementara pengguna terdaftar dapat mengunggah video dalam jumlah tak terbatas. Video-video yang dianggap berisi konten ofensif hanya bisa ditonton oleh pengguna terdaftar berusia 18 tahun atau lebih. Pada November 2006, YouTube, LLC dibeli oleh Google dengan nilai US $\$ 1,65$ miliar dan resmi beroperasi sebagai anak perusahaan Google.

\section{Debat}

Dalam Kamus Besar Bahasa Indonesia, debat berarti pembahasan dan pertukaran pendapat mengenai suatu hal dengan saling memberi alasan untuk mempertahankan pendapat masing-masing.

Sementara menurut Wikipedia, debat adalah kegiatan adu argumentasi antara dua pihak atau lebih, baik secara perorangan maupun kelompok, dalam mendiskusikan dan memutuskan masalah dan perbedaan. Secara formal, debat banyak dilakukan dalam institusi legislatif seperti parlemen, terutama di negara-negara yang menggunakan sistem oposisi. Dalam hal ini, debat dilakukan menuruti aturan-aturan yang jelas dan hasil dari debat dapat dihasilkan melalui voting atau keputusan juri.

Contoh lain debat yang diselenggarakan secara formal adalah debat antar kandidat legislatif dan debat antar calon presiden/wakil presiden yang umum dilakukan menjelang pemilihan umum.

\section{Pilkada DKI 2017}

Dalam Wikipedia disebutkan bahwa Pemilihan umum Gubernur DKI Jakarta 2017 (disingkat Pilgub Jakarta 2017 atau Pilgub DKI 2017) dilaksanakan pada 15 Februari 2017 dan 19 April 2017 untuk menentukan Gubernur dan Wakil Gubernur DKI Jakarta periode 2017-2022. Ini merupakan pemilihan kepala daerah ketiga bagi Jakarta yang 
dilakukan secara langsung menggunakan sistem pencoblosan.

Jadwal pemilihan periode ini dimajukan dari jadwal pemilihan periode sebelumnya, yaitu 11 Juli karena mengikuti jadwal Pilkada Serentak gelombang kedua pada 2017. Berdasarkan peraturan, hanya partai politik yang memiliki 22 kursi atau lebih di DPRD Jakarta yang dapat mengajukan kandidat. Partai politik yang memiliki kursi kurang dapat mengajukan calon hanya jika mereka telah memperoleh dukungan dari partai politik lainnya.

Gubernur Basuki Tjahaja Purnama (dikenal sebagai "Ahok") mencalonkan diri sebagai petahana bersama dengan Djarot Saiful Hidayat. Selain itu, mantan perwira TNI Agus Harimurti Yudhoyono bersama dengan Sylviana Murni, serta akademisi dan mantan Menteri Pendidikan dan Kebudayaan Indonesia Anies Baswedan juga mencalonkan diri bersama dengan Sandiaga Uno

\section{METODE PENELITIAN Pendekatan Kualitatif}

Penelitian kualitatif adalah penelitian yang bersifat empiris (dapat diamati dengan pancaindera sesuai dengan kenyataan), dengan pengamatan atas data tidak didasarkan pada ukuran-ukuran matematis yang terlebih dulu ditetapkan peneliti dan harus disepakati (direplikasi) oleh pengamatan lain, tetapi berdasarkan ungkapan subjek penelitian, sebagaimana yang dikehendaki dan dimaknai oleh subjek penelitian. Pendekatan kualitatif menggunakan konsep kealamiahan (kecermatan, kelengkapan, atau orisinalitas) data dan apa yang sebenarnya terjadi di lapangan.

Pendekatan kualitatif terutama layak untuk menelaah sikap atau perilaku dalam lingkungan yang agak artifisial, seperti dalam survei atau eksperimen. Peneliti kualitatif lebih menekankan proses dan makna ketimbang kuantitas, frekuensi atau intensitas (yang secara matematis dapat diukur), meskipun peneliti tidak mengharamkan statistik deskriptif dalam bentuk distribusi frekuensi atau presentase untuk melengkapi analisis datanya (Mulyana, 2007:11).

\section{Etnografi Virtual}

Etnografi virtual adalah metode etnografi yang dilakukan untuk melihat fenomena sosial dan kultur pengguna di ruang siber (Nasrullah, 2014: 171). Etnografi virtual mempertanyakan asumsi yang sudah berlaku secara umum tentang internet, menginterpretasikan sekaligus reinterpretasi internet sebagai sebuah cara sekaligus medium yang digunakan untuk berkomunikasi, merupakan "ethnography in, of and trough the virtual" - interaksi tatap muka atau face to face tidak diperlukan (Hine, 2001).

Tom Boellstorff, professor di bidang antropologi University of California, US menyatakan bahwa penelitian etnografi virtual, pada dasarnya memiliki prinsipprinsip yang sama dengan penelitian etnografi, dimana proses melakukan dan membangun etnografi menggunakan lingkungan virtual online sebagai lokasi penelitian.

Boellstorf menyatakan bahwa pengumpulan data penelitian diluar lokasi (dunia virtual) penelitian sama saja dengan melanggar prinsip "in their own term", karena bagaimanapun juga segala sesuatu memiliki makna dalam konteksnya sendiri.

Dalam etnografi virtual, wawancara dan survei dapat digantikan oleh koleksi/arsip yang sudah ada yang berasal dari informasi yang melimpah di lingkungan online seperti situs jejaring sosial dan forum internet. Informasi dapat ditemukan dan diarsipkan dari internet tanpa harus dicatat dan ditulis seperti etnografer tradisional (Evans, 2010:2).

\section{PEMBAHASAN}

Adapun komentar kasar yang diberikan netizen terkait video Debat Final Pilkada DKI 2017 di channel YouTube CNN Indonesia adalah: 
- Netizen kerap menghina pasangan calon yang bukan pilihannya

Hal ini sangat disayangkan karena ketika netizen menghina pasangan calon lain, netizen menggunakan bahasa yang kasar dan tidak pantas, bahkan kotor. Ini tentu sangat disayangkan karena kata-kata yang disampaikan tidak mencerminkan nilai-nilai budaya Indonesia yang menjunjung tinggi nilai kesopanan dan keramahan. Netizen seharusnya dapat menahan diri dengan menanyakan atau mengkritisi program serta jawaban pasangan calon dengan menggunakan bahasa yang sopan dan santun.

- Netizen saling menghina netizen lain yang mendukung salah satu pasangan calon

Hal ini lebih memprihatinkan lagi karena yang menjadi sasaran netizen bukan lagi pasangan calon yang sedang bertarung di Pilkada, tetapi netizen pendukung pasangan calon. Dan mereka bisa terus menerus membalas di media social terkait hinaan yang saling dilontarkan. Mereka tidak saling kenal, tetapi mereka saling mengejek, menghina menggunakan bahasa yang kasar, kotor, dan tidak sopan. Yang mejadi objek hinaan, sindiran bukan lagi program atau jawaban pasangan calon di debat pilkada, tetapi hal-hal personal terkait yang mereka tampilkan di media social - nama atau profil picture

- Netizen saling berdebat dengan netizen lain terkait pasangan calon pilihannya.

Ini menjadi hal yang tidak sehat ketika netizen merasa bahwa calonnya lebih unggul daripada pilihan netizen lain. Debat kusir tentu akan terjadi, dan perselisihan dalam kolom komentar terus terjadi. Debat akan terhenti jika salah satu netizen menghentikan komentarnya, dan tidak membalas komentar netizen lain yang pilihannya berbeda dengan dirinya.

\section{Temuan}

Netizen masih belum dewasa menyikapi Debat Final Pilkada DKI 2017. Netizen terlampau mengedepankan egonya, dan tidak mampu menahan diri untuk tidak berdebat atau menghina netizen lain. Bahkan kata-kata seperti goblok, bodoh, bego, omdo, bullshit, dan dongo menjadi sesuatu yang disampaikan tanpa rasa sungkan dan malu. Tentu ini menjadi perhatian, bahwa netizen Indonesia masih kasar dalam bersikap dan berkata.

\section{KESIMPULAN}

a. Komentar kasar netizen terkait isi video Debat Final Pilkada DKI 2017 di channel YouTube adalah: 1) netizen kerap menghina pasangan calon yang bukan pilihannya, 2) netizen saling menghina netizen lain yang mendukung salah satu pasangan calon, dan 3) netizen saling berdebat dengan netizen lain terkait pasangan calon pilihannya.

b. Netizen tidak sungkan menyampaikan kata-kata goblok, bodoh, bego, omdo, bullshit, dan dongo pada netizen lainnya di media social YouTube. Netizen Indonesia masih kasar dalam bersikap dan berkata.

\section{DAFTAR PUSTAKA}

\section{Buku}

Ardianto, E.L.( 2004). Komunikasi Massa: Suatu Pengantar. Bandung: SimbiosaRekatama Media

Boellstorff, Tom. 2008. Coming of Age in Second Life : An Anthropologist Explores The Virtually Human. New Jersey: Princenton University Press

Fajar, Marhaeni.( 2009). Ilmu komunikasi: Teori \& Praktek. Yogyakarta: Graha Ilmu 
Hine, Christine. (2001). Virtual Ethnography. London: Sage Publication Ltd.

Lasswell, Harold D. (1972). The structure and function of communication in society dalam Wilbur Schramm, ed. Mass communication. Urbana - Chicago: University of Illinois Pres

Mulyana, Deddy. \& Solatun. (2007). Metode Penelitian Komunikasi. Bandung: PT. Remaja Rosdakarya

Nasrullah, Rulli. (2014). Teori dan Riset Media Siber (Cybermedia). Jakarta:Kencana

\section{Sumber Elektronik/ Internet}

Amalia, Ellavie Ichlasa. (2016). Bos YouTube: Penonton TV Berkurang, Penonton Kami Bertambah. Diakses pada 23 Agustus 2016, dari http://teknologi.metrotvnews.com/new s-teknologi/Obz9BJeN-bos-YouTubepenonton-tv-berkurang-penontonkami-bertambah

Bohang, Fatimah Kartini. (2015). TV Ditinggalkan, Ini Tontonan Favorit Baru Orang Indonesia. Diakses pada 23 Agustus 2016, dari http://tekno.kompas.com/read/2015/11 /25/12310007/TV.Ditinggalkan.Ini.To ntonan.Favorit.Baru.Orang.Indonesia

Kementerian Komunikasi dan Informatika Republik Indonesia. (2014). Pengguna Internet Indonesia Nomor Enam Dunia. Diakses pada 23 Agustus 2016, dari

https://kominfo.go.id/content/detail/42 86/pengguna-internet-indonesianomor-enam-dunia/0/sorotan_media 
